\title{
Strategies in Clinical and Laboratory Diagnosis of Inherited Platelet Function Disorders in Children
}

\author{
Ralf Knöfler ${ }^{\mathrm{a}} \quad$ Werner Streif ${ }^{b}$ \\ a Children's Hospital, Carl Gustav Carus Dresden University Hospital, Dresden, Germany \\ ${ }^{\mathrm{b}}$ Department of Paediatrics, Innsbruck Medical University, Innsbruck, Austria
}

\section{Keywords}

Blood platelet disorders .

Inherited thrombocytopathies · Diagnosis · Children

\section{Summary}

Inherited disorders of platelet function are a rare and heterogeneous group of diseases usually characterised by a mild to moderate bleeding tendency. Typical bleeding symptoms are easy bruising, epistaxis, menorrhagia as well as mucocutaneous and perioperative bleeding. The performance of platelet function diagnostics in children is hampered by age-dependent restriction of blood sample size, poor venous access, and the lack of reproducible test reference ranges for children of different age groups. Platelet function testing is limited to specialised centres, because platelet function test procedures are complicated and time-consuming, which most likely results in a relevant number of undiagnosed and incorrectly classified children with clinically relevant platelet function defects. Evaluation of bleeding history and bleeding symptoms is essential for a rational step-bystep approach to diagnosis. Platelet function diagnostics should be preceded by the exclusion of thrombocytopenia, von Willebrand disease, and secondary haemostasis defects. Light transmission aggregometry is still considered the standard for the assessment of platelet function. Every effort should be made to classify the specific platelet function defect in the patient, because this is essential for accurate treatment and counselling.

\author{
Schlüsselwörter \\ Thrombozytenfunktionsdefekte . \\ Hereditäre Thrombozytopathien · Diagnose · Kinder
}

\section{Zusammenfassung}

Angeborene Thrombozytenfunktionsstörungen stellen eine seltene und heterogene Gruppe von Erkrankungen dar, welche meist durch eine leichte bis mittelschwere Blutungsneigung auffallen. Typische Blutungssymptome sind Hämatomneigung, Epistaxis, Menorrhagien sowie Schleimhaut- und perioperative Blutungen. Die Durchführung der Thrombozytenfunktionsdiagnostik bei Kindern wird erschwert durch die altersabhängig begrenzte Blutprobenmenge, schwierige Venenverhältnisse und das Fehlen von Referenzbereichen für Kinder unterschiedlichen Alters. Aufgrund der meist komplizierten und zeitaufwendigen Tests ist die Thrombozytendiagnostik auf spezialisierte Zentren begrenzt. Mit hoher Wahrscheinlichkeit wird eine relevante Anzahl von Kindern mit nichtdiagnostizierten bzw. unkorrekt klassifizierten, klinisch relevanten Thrombozytopathien übersehen. Die Erhebung der Blutungsanamnese und die Bewertung der Blutungssymptome sind erforderlich für eine stufenweise erfolgreiche Gerinnungsdiagnostik. Vor Durchführung einer Thrombozytenfunktionsdiagnostik sollten das Vorliegen einer Thrombozytopenie, einer von-Willebrand-Erkrankung und sekundärer Gerinnungsstörungen ausgeschlossen werden. Die Lichttransmissionsaggregometrie gilt noch immer als Standardmethode für die Beurteilung der Thrombozytenfunktion. Nach Möglichkeit sollte stets versucht werden, den vorliegenden spezifischen Thrombozytenfunktionsdefekt zu klassifizieren, da dies für eine adäquate Behandlung und eine gezielte genetische Beratung notwendig ist.

\begin{tabular}{ll}
\hline KARGER & @ 2010 S. Karger GmbH, Freiburg \\
Fax +497614520714 & Accessible online at: \\
Information@Karger.de & www.karger.com/tmh \\
www.karger.com &
\end{tabular}




\section{Introduction}

Inherited platelet function defects (PFD) are a rare and heterogeneous group of disorders [1]. Bleeding symptoms differ widely. Due to the fact that the majority of affected patients present with a mild to moderate bleeding tendency, many patients are not diagnosed during childhood. However, following trauma and surgery unexpected extensive bleeding may occur. For this reason, when normal coagulation screening results are accompanied by unexplained conspicuous bleeding symptoms, testing for PFD is mandatory $[2,3]$.

However, selection and performance of tests of platelet function may be difficult in children. For most tests, accurate and generalisable reference ranges for children of different age groups have not yet been determined. Poor venous access and restrictions in blood sample size, especially in younger children with suspected platelet disorders, frequently hinder a complete laboratory work-up [3].

Testing for platelet function is performed only by a relatively small number of highly specialised laboratories, often affiliated with major hospitals and clinics. Consequently, diagnosed cases are frequently clustered around such laboratories, while elsewhere an unknown but probably relevant number of cases remain undiagnosed or incorrectly classified [4,5].

This article summarises current knowledge on the diagnostic approach to children with suspected inherited disorders of platelet function. Presented information includes data from the THROMKID Quality Project of the Permanent Paediatric Group of the German Thrombosis and Haemostasis Research Society (GTH). The main part of this study was a collaborative patterns-of-practice survey intended to overview diagnosis and treatment of patients with functional platelet abnormalities in Austria, Germany, and Switzerland [6, 7].

\section{Incidence of Inherited Thrombocytopathies}

Most disorders of platelet function are described in a very small number of patients. The true incidence is still unknown [4]. Due to the mild to moderate bleeding tendency in most affected children, defects may frequently remain undiagnosed until the haemostatic system is challenged, e.g. during major surgery. The THROMKID Quality Project revealed 1.3-2.2 affected children per one million inhabitants in the German-speaking countries [7]. Only in about half $(\mathrm{n}=122)$ of the 215 identified children were defects well-classified. Of these children, 39 (32\%) presented with Glanzmann thrombasthenia, followed by aspirin-like defects $(n=26,21 \%)$, platelet receptor defects $(n=20,17 \%)$, storage pool disorders $(n=18,15 \%)$, Bernard-Soulier syndrome $(\mathrm{n}=10,8 \%)$, Hermansky-Pudlak syndrome $(\mathrm{n}=6$, $5 \%$, and MYH9-related macrothrombocytopenia syndromes $(\mathrm{n}=3,2 \%)$.

\section{Standardised Questionnaires for Identification of Children with Bleeding Disorders}

In general, laboratory tests for haemostasis are ordered on the basis of bleeding symptoms and/or a positive bleeding history. In order to identify, diagnose, and treat children at risk for bleeding, including taking general clinical steps to prevent bleeding, a detailed family and individual history of bleeding type and severity is crucial, particularly when proper classification of the underlying haemostasis disorder is lacking.

The significance of compiling a standardised bleeding history by using a structured questionnaire for preoperative bleeding risk assessment in children has been well documented, but only few questionnaires have focused on the detection of haemostatic disorders in children [8-10]. Questionnaires for diagnosis of haemostatic disorders are voluminous and time-consuming and have not been introduced into clinical practice so far [11, 12].

Severe haemophilia is typically associated with haemarthroses; muscle bleeds and intracranial bleeds are rare. By contrast, platelet defects primarily result in easy bruising, epistaxis, mucosal and oral cavity bleeding, invasive procedure-related bleeding, and menorrhagia in older girls. Clinical diagnosis is often difficult since easy bruising and epistaxis are also common in healthy children [13]. Most affected children display only few bleeding symptoms, which underlines the importance of evaluating their family history. The THROMKID Quality Project revealed that the family bleeding history was conspicuous in more than half of the children with PFD [14].

\section{Algorithm for Diagnosis of Inherited Haemostatic Disorders in Clinical Practice}

Children with severe or prolonged bleeding and/or unexplained bleeding and/or a positive individual and/or family history of bleeding should undergo coagulation testing. The algorithm shown in figure 1 incorporates the results of the THROMKID Quality Project, in which cooperating centres reported the diagnostic approach to children with suspected inherited defects of platelet function and bleeding of unknown cause. The cooperating centres reported a similar approach irrespective of the clinical scenario, including acute bleeding and positive, individual, and family history of bleeding [15].

Before testing platelet function, the following must be excluded: medication interfering with haemostasis such as NSAR, severe infection, immune thrombocytopenia, and defects of secondary haemostasis such as haemophilia A/B and von Willebrand disease as the most common hereditary haemorrhagic disorder. It must always be remembered that many inherited platelet disorders are associated with low platelet counts [16]. Some platelet defects are associated with wide-ranging symptom complexes that include defects of the immune system, hearing loss, albinism, impairment of renal 
Fig. 1. Algorithm for diagnostic approach to children with suspected inherited disorders of platelet function. a Detailed algorithm in [4]. ' Detailed algorithm in [16]. aPTT $=$ Activated partial thromboplastin time; VWF:Ag = von Willebrand factor antigen; VWD = von Willebrand disease; $\mathrm{PT}=$ prothrombin time, VWF: $\mathrm{CB}=$ collagen binding activity; VWF:RCo $=$ Ristocetin cofactor; ITP = immune thrombocytopenia.
Bleeding symptoms and/or positive bleeding history (acquired haemostatic disorders by infection, medication etc. excluded)

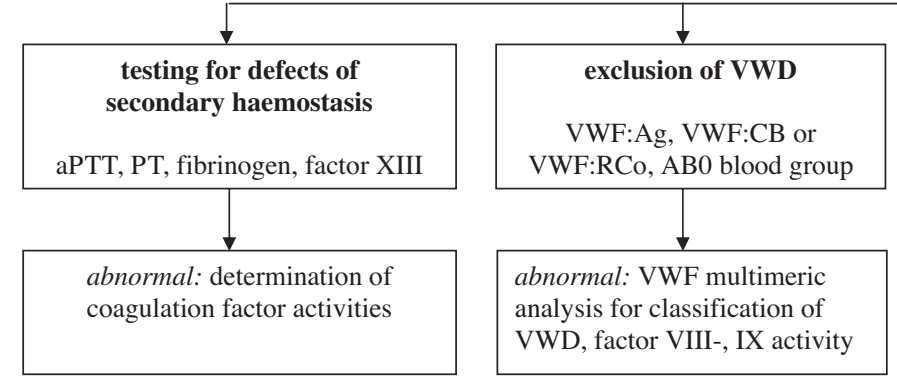

tests for platelet abnormalities

platelet count, mean volume, morphology

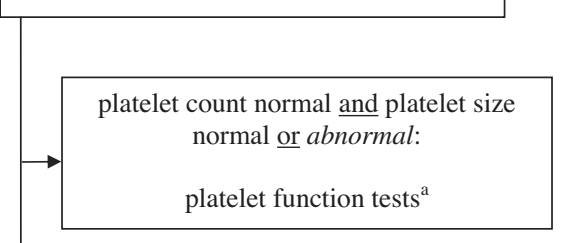

thrombocytopenia present and ITP and VWD type $2 \mathrm{~B}$ excluded

platelet function tests ${ }^{\mathrm{a}, \mathrm{b}}$ function, and other symptoms [4]. Application of the algorithm can support and guide clinicians in identifying and classifying the suspected haemostatic defect (fig. 1).

The THROMKID Quality Project, performed in coagulation laboratories in German-speaking countries, revealed that specific testing of platelet function is often preceded by screening tests for primary haemostasis, such as the in vivo bleeding time (BT), the Platelet Function Analyzer (PFA) $100^{\circledR}$ test, and thrombelastography. However, these tests are of limited value. The in vivo bleeding time is a time-consuming test that requires an experienced operator and patient cooperation, something often lacking in children. Studies have not clearly established the ability of BT to predict an individual's bleeding risk $[17,18]$. Many centres have replaced the in vivo BT with the PFA $100^{\circledR}$, but the test lacks specificity as a screening tool for platelet disorders $[2,19]$. Thrombelastography has been shown to be useful as a point-of-care means of assessing perioperative coagulability as well as guiding and reducing replacement therapy for blood loss and dilutional coagulopathy. The use of this test for screening for platelet defects is also limited because of its lacking specificity.

\section{Algorithm for Diagnosis of Inherited Platelet Function Disorders in Clinical Practice}

Determination of platelet function in children does not essentially differ from that in adult patients. The limited blood volume available calls for an algorithm for choosing appropriate platelet tests (fig. 1, table 1). In the case of newborns and infants without bleeding symptoms, but with a conspicuous family history, it may be preferable to start testing in possibly affected adult family members and to defer testing in the child.
For clinical decision-making, clinicians are well advised to rely on their clinical judgement and on a limited number of preferably simple, robust, and available tests at their centre. In many cases this line of action will at least confirm or rule out the tentative diagnosis of a PFD. However, every effort should be made to classify the specific PFD using highly specialised assays such as electron microscopy and molecular genetic methods [20, 21]. Classification of PFDs is essential for accurate counselling and treatment.

Most of the specific platelet function testing methods recently described by authors in great detail are difficult to perform, time-consuming, and need freshly drawn samples of venous blood [22]. However, the initial steps in investigating platelet function disorders - the determination of platelet count and the assessment of mean platelet size - may be performed with any commonly used automated counter. Reference ranges for platelet count and mean platelet volume in children do not differ from those for adults. Just recently, Althaus et al. [23] published a new method for diagnosing structural platelet defects such as congenital macrothrombocytopenic disorders from peripheral blood smears, which are easy to obtain even in very young children.

Light transmission aggregometry (LTA) is poorly standardised and requires relatively large volumes of freshly drawn blood, but is still considered the 'gold standard' for the evaluation of platelet function; this was confirmed by the THROMKID Quality Project [6, 24]. Recently, the Clinical and Laboratory Standards Institute (CLSI), the Platelet Physiology Subcommittee of the SSC of the International Society on Thrombosis and Haemostasis (ISTH), and the North American Specialised Coagulation Laboratory Association (NASCOLA) published extensive surveys and guidelines on the standardisation of LTA [25-27]. In healthy children older 
Table 1. Stratification of platelet tests for diagnosis of inherited platelet function defects in children

\begin{tabular}{|c|c|c|}
\hline $\begin{array}{l}\text { Value of commonly used tests for } \\
\text { diagnosis of inherited platelet defects } \\
\text { (poor '-'; fair '0'; good '+') }\end{array}$ & $\begin{array}{l}\text { Basic test panel } \\
\text { (orientation; rational approach) }\end{array}$ & $\begin{array}{l}\text { Extended test panel } \\
\text { (confirmation/characterisation approach) }\end{array}$ \\
\hline $\begin{array}{l}\text { Standard microscopy of stained } \\
\quad \text { blood smears '+' } \\
\text { PFA 100-test '-' } \\
\text { In vivo bleeding time '-' } \\
\text { Thrombelastography '-' } \\
\text { LTA '+' } \\
\text { IA '0' } \\
\text { Luminometry '+' } \\
\text { Flow cytometry '+' } \\
\text { Electron microscopy '+' } \\
\text { Genetics '0' }\end{array}$ & $\begin{array}{l}\text { platelet volume and platelet size } \\
\text { determination (counter and } \\
\text { blood smear examination) } \\
\text { platelet aggregation (LTA or IA } \\
\text { using a panel of different } \\
\text { agonists - ADP, arachidonic acid, } \\
\text { or epinephrine, collagen) } \\
\text { platelet adhesion assays }\end{array}$ & $\begin{array}{l}\text { platelet secretion (luminometric } \\
\text { determination of ATP release, serotonin- } \\
\text { releasing assay, mepacrine uptake) } \\
\text { platelet glycoprotein expression flow } \\
\text { cytometry } \\
\text { platelet ultrastructure / morphology } \\
\text { (electron microscopy, immuno- } \\
\text { fluorescence microscopy, confocal } \\
\text { microscopy) } \\
\text { genetic analysis (molecular genetics } \\
\text { methods) }\end{array}$ \\
\hline
\end{tabular}

$\mathrm{ADP}=$ Adenosine diphosphate LTA = light transmission aggregometry $;$ ATP = adenosine triphosphate; $\mathrm{PFA}=$ platelet function analyzer; IA = impedance aggregometry.

Table 2. Reference values for light transmission aggregometry / adenosine triphosphate (ATP) release using the Chrono-log lumi-aggregometer (Chrono-log Corp., Havertown, PA, USA) in platelet rich plasma from healthy children and adults. Final concentrations of agonists are stated in brackets. Values are expressed as median of maximal percentage aggregation within 6 min after addition of agonist with the interval covering $95 \%$ of the population studied (between 2.5 th and 97.5 th centiles); table modified from [29]

Table 3. Reference values of impedance aggregometry / adenosine triphosphate (ATP) release using the Chrono-log lumi-aggregometer in whole blood from healthy children and adults. Final concentrations of agonists are stated in brackets. Values are expressed as mean values $\pm 1 \mathrm{SD}$ of maximal aggregation within 6 min after addition of agonist; table modified from $[28]$

\begin{tabular}{|c|c|c|c|}
\hline Group & $<28$ days & $1-17$ years & Adults \\
\hline Patients, $\mathrm{n}$ & 25 & 19 & 35 \\
\hline Age, range & 4 days $(1-12)$ & 9.3 years $(1-17)$ & not determined \\
\hline ADP $\left(20 \mu \mathrm{mol} \mathrm{l}^{-1}\right)$, ohms & $22.7 \pm 7.3$ & $23.5 \pm 9.1$ & $18.2 \pm 5.6$ \\
\hline $\operatorname{ADP}\left(20 \mu \mathrm{mol} \mathrm{l}^{-1}\right), \mathrm{nmol}^{\mathrm{a}}$ & $1.30 \pm 0.56$ & $1.64 \pm 1.1$ & $1.02 \pm 0.48$ \\
\hline Arachidonic $\left(1 \mathrm{mmol} \mathrm{l}^{-1}\right)$, ohms & $23.9 \pm 5.4$ & $21.7 \pm 8.5$ & $21.3 \pm 3.0$ \\
\hline Arachidonic $\left(1 \mathrm{mmol} \mathrm{l}^{-1}\right), \mathrm{nmol}^{\mathrm{a}}$ & $0.92 \pm 0.37$ & $0.79 \pm 0.47$ & $0.80 \pm 0.26$ \\
\hline Collagen $\left(1 \mu \mathrm{g} \mathrm{ml}^{-1}\right)$, ohms & $25.0 \pm 6.6$ & $33.4 \pm 7.5$ & $33.0 \pm 9.7$ \\
\hline Collagen $\left(1 \mu \mathrm{g} \mathrm{ml}^{-1}\right), \mathrm{nmol}^{\mathrm{a}}$ & $0.39 \pm 0.18$ & $0.91 \pm 0.46$ & $0.86 \pm 0.24$ \\
\hline $\operatorname{Thrombin}^{\mathrm{a}}\left(0.5 \mathrm{U} \mathrm{ml}^{-1}\right), \mathrm{nmol}^{\mathrm{a}}$ & $0.93 \pm 0.27$ & $1.24 \pm 0.64$ & $1.39 \pm 0.43$ \\
\hline Ristocetin $\left(1.25 \mathrm{mg} \mathrm{ml}^{-1}\right)$, ohms & $23.3 \pm 8.5$ & $19.6 \pm 9.1$ & $27.9 \pm 9.4$ \\
\hline
\end{tabular}

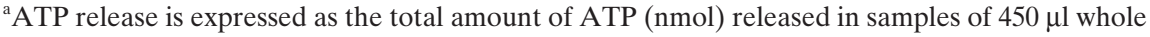
blood.

ADP $=$ Adenosine diphosphate. 
than 1 year, LTA in platelet-rich plasma, impedance aggregometry (IA) in whole blood, and luminometric detection of adenosine triphosphate release from platelet-dense granules do not differ from those in adult controls, which suggests that established adult normal ranges may be used in children beyond 1 year of age (table 2, 3) [28, 29].

\section{Conclusion}

Bleeding symptoms such as cutaneous haematoma and epistaxis are quite common in children. Evaluation of bleeding history using a standardised questionnaire and a careful, clinical examination may enable clinicians to differentiate between 'normal' and a suspected bleeding disorder. After per- forming screening tests for platelet function and confirming an inherited platelet defect, these children should be referred to a nearby diagnostic centre. Because of the broad range of possible investigations often needed to evaluate mild to moderate bleeding, a rational and step-by-step approach to diagnosis may save time and resources. Such diagnostic centres in the German-speaking countries can be located on the website of the GTH (www.gth-online.org/home/paediatrische-gth/ kompetenznetz).

\section{Disclosure}

The authors declared no conflict of interest.

\section{References}

1 Nurden AT: Qualitative disorders of platelets and megakaryocytes. J Thromb Haemost 2005;3:17731782.

2 Hayward CP, Rao AK, Cattaneo M: Congenital platelet disorders: overview of their mechanisms, diagnostic evaluation and treatment. Haemophilia 2006;12(suppl 3):128-136.

3 Israels SJ: Diagnostic evaluation of platelet function disorders in neonates and children: an update. Semin Thromb Hemost 2009;35:181-188.

$\checkmark 4$ Bolton-Maggs PHB, Chalmers EA, Collins PW, Harrison P, Kitchen S, Liesner RJ, Minford A, Mumford AD, Parapia LA, Perry DJ, Watson SP, Wilde JT, Williams MD: A review of inherited platelet disorders with guidelines for their management on behalf of the UKHCDO. Br J Haematol 2006;135:603-633.

5 Favaloro EJ, Bonar R, Kershaw G, Duncan E, Sioufi J, Marsden K: Investigations from externa quality assurance programs reveal a high degree of variation in the laboratory identification of coagulation factor inhibitors. Semin Thromb Hemost 2009;35:794-805.

6 Streif W, Olivieri M, Weickardt S, Eberl W, Knöfler R: Thromkid - a competence network for functional platelet abnormalities. Transfus Med Hemother 2007;34:56-62.

7 Knöfler R, Olivieri M, Weickardt S, Eberl W, Streif W: First results oft he THROMKID study: a quality project for the registration of children and adolescents with hereditary platelet function defects in Germany, Austria and Switzerland. Hamostaseologie 2007;27:48-53.

8 Music I, Novak M, Acham-Roschitz B, Muntean W: Screening for haemorrhagic disorders in paediatric patients by means of a questionnaire. Hamostaseologie 2009;29(suppl 1):S87-S89.

9 Bidlingmaier C, Eberl W, Knöfler R, Olivieri M, Kurnik K: Haemostatic testing prior to elective surgery in children? Not always! Hamostaseologie 2009;29:64-67.

10 Eberl W, Wendt I, Schroeder HG: Preoperative coagulation screening prior to adenoidectomy and tonsillectomy. Klin Padiatr 2005;217:20-24.
11 Hedlund-Treutiger I, Revel-Vilk S, Blanchette VS, Curtin JA, Lillicrap D, Rand ML: Reliability and reproducibility of classification of children as 'bleeders' versus 'non-bleeders' using a questionnaire for significant mucocutaneous bleeding. J Pediatr Hematol Oncol 2004;26:488-491.

12 Biss TT, Blanchette VS, Clark DS, Bowman M, Wakefield CD, Silva M, Lillicrap D, James PD, Rand ML: Quantitation of bleeding symptoms in children with von Willebrand disease: use of a standardized pediatric bleeding questionnaire. J Thromb Haemost 2010;8:950-956.

13 Khair K, Liesner R: Bruising and bleeding in infants and children - a practical approach. Br J Haematol 2006;133:221-231.

14 Knöfler R, Olivieri M, Weickardt S, Eberl W, Streif W: Evaluation of family histories in pediatric patients with hereditary thrombocytopathies: results from the THROMKID study. J Thromb Haemost 2009; 7(suppl 2):AS-TH-055 (abstract).

15 Streif W, Martin O, Stefan W, Wolfgang E, Ralf $\mathrm{K}$, on behalf of the Thromkid Study Group of the GTH: Testing for inherited platelet defects in clinical laboratories in Germany, Austria and Switzerland. Results of a survey carried out by the Permanent Paediatric Group of the German Thrombosis and Haemostasis Research Society (GTH). Platelets 2010;21:470-478

16 Balduini CL, Cattaneo M, Fabris F, Gresele P, Iolascon A, Pulcinelli FM, Savoia A: Inherited thrombocytopenias: a proposed diagnostic algorithm from the Italian Gruppo di Studio delle Piastrine. Haematologica 2003;88:582-592.

17 Rodgers RP: Bleeding time tables. A tabular summary of pertinent literature. Semin Thromb Hemost 1990;16:21-138.

18 Lind SE: The bleeding time does not predict surgical bleeding. Blood 1991;77:2547-2552.

19 Quiroga T, Goycoolea M, Munoz B, Morales M, Aranda E, Panes O, Pereira J, Mezzano D: Template bleeding time and PFA- $100^{\circledR}$ have low sensitivity to screen patients with hereditary mucocutaneous hemorrhages: comparative study in 148 patients. J Thromb Haemost 2004;2:892-898.
20 Clauser S, Cramer-Bordé E: Role of platelet electron microscopy in the diagnosis of platelet disorders. Semin Thromb Hemost 2009;35:213-223.

21 Nurden AT, Fiore M, Pillois X, Nurden P: Genetic testing in the diagnostic evaluation of inherited platelet disorders. Semin Thromb Hemost 2009;35:204-212.

22 Streif W, Knöfler R, Eberl W: Inherited disorders of platelet function in pediatric clinical practice: a diagnostic challenge. Klin Padiatr 2010;222:203208.

23 Althaus K, Blumentritt C, Stein K, Greinacher A: Blood smear microscopy - diagnosis of inherited platelet disorders by immunostaining. Hamostaseologie 2010;30:A72 (abstract).

24 McGlasson DL, Fritsma GA: Whole blood platelet aggregometry and platelet function testing. Semin Thromb Hemost 2009;35:168-180.

25 Cattaneo M, Hayward CP, Moffat KA, Pugliano MT, Liu Y, Michelson AD: Results of a worldwide survey on the assessment of platelet function by light transmission aggregometry: a report from the platelet physiology subcommittee of the SSC of the ISTH. J Thromb Haemost 2009; 7:1029.

26 Christie DJ: Platelet Function Testing by Aggregometry; Proposed Guideline. Wayne, PA, Clinical and Laboratory Standards Institute, 2007, pp 1-46.

27 Moffat KA, Ledford-Kraemer MR, Nichols WL, Hayward CP: Variability in clinical laboratory practice in testing for disorders of platelet function: results of two surveys of the North American Specialized Coagulation Laboratory Association. Thromb Haemost 2005;93:549-553.

28 Knöfler R, Weissbach G, Kuhlisch E: Platelet function tests in childhood. Measuring aggregation and release reaction in whole blood. Semin Thromb Hemost 1998;24:513-521.

29 Bonduel M, Frontroth JP, Hepner M, Sciuccati G, Feliu-Torres A: Platelet aggregation and adenosine triphosphate release values in children and adults. J Thromb Haemost 2007;5:1782-1787. 